\title{
Improving the Standard and Quality of Primary Education in Nigeria: A Case Study of Oyo and Osun States
}

\author{
Sofowora Olaniyi Alaba \\ Obafemi Awolowo University, Nigeria
}

\begin{abstract}
This study discusses government effort at ensuring quality education at the primary school in the south western Nigeria. Triangulation approach was employed. Six hundred teachers were selected through stratified sampling techniques. Data was collected using a questionnaire on 4 point Likert rating scale. The results showed that $54 \%$ of the schools in the 2 states are yet to implement the 1:30 teacher pupil's ratio as stipulated in the National Policy on Education. School Attendance Registers $(F=0.059$, df $(1,526) p$,> 0.809) and Record of Works are badly kept in the schools in the schools ( $F$ 0.11,df $=(1,52) 1 p>0.7)$. The classroom test and examination questions given to the students are defective and not reliable ( $F=$ $0.22, d f=(1,513) P>0.83)$. Also the language of construction was bad $(F=0.439, d f=(1,519) \quad p$ $>0.539)$. It was also revealed that there were more female teachers (66\%) than made (31\%). Most schools were also found to lack Elementary Science Laboratory as stipulated in the National Policy on Education $(F=0.469,(d f=1.513) p>0.883)$.
\end{abstract}

\section{Introduction}

In realization of the important role which education plays as an agent of National development and globalization, there has been agitation for more functional and qualitative education all over the world. This agitation and concern for quality education is reflected in the inauguration of Education for All (EFA) in Jomtien (Thailand) in 1995 and Dakar in 2000. This was followed by a meeting called by the $56^{\text {th }}$ General Assembly of the United Nations to discuss the implementation of the Millennium Development Goals (MDGs).

The effort at ensuring quality was not left to these bodies alone, other societies like Society for Information Technology and Teacher Education (SITE), Association for the Advancement of Computing in Education (AACE) and the Infonomics Society also sponsored and organized international conferences and workshops aimed at ensuring quality and access to education. However, at the global level the United Nations came up with a target that all member states should achieve. They include:
- ensuring that by the year 2015 all children particularly girls, children in difficult circumstances and those belonging to the ethnic minorities have access to a complete free compulsory and good quality primary education.

- ensure that the learning needs of all young people and adults are in line with the MDGs

- eradicate extreme poverty and hunger,

- achieve universal primary education by 2015 [12].

Nigeria as one of the signatory countries was compelled to implement this UNESCO [12] mandate to provide high standard and good quality primary education for every child. In 1999 president Obasanjo launched the Universal Basic Education (UBE) as strategy to bring quality education to every child. Omotayo, Ihebereme and Maduewesi [7] identify poor implementation strategy, management and lack of quality assurance as responsible factors for the failure to realize the goals of UBE [7].

According to Egwu [5], other problems facing primary education are: wide disparity between the expected school enrolment and the actual enrolment. Poor management of information leads to conflicting statistics about the number of primary schools. One source put it at 54,434 public primary schools another source from school census put the number at 87,941 and an enrolment figure of $24,422,918$. Out of which males are $13,302,262$ (55\%) while female figure is $11,120,649$ (45\%), indicating gender imbalance of (83.6\%). The above statistics revealed that there is a shortfall of 10.5 million from the expected target of 34.92 million set. The inability of the country to meet the target set, according the late Professor Fafunwa as quoted by Omotayo [7], include: financial problems, incompetent teachers, over crowded classrooms, narrow curriculum content, high rate of drop-outs and lack of quality control. These problems then led to the decline in standard at all levels of Education. The reason for the above is that Nigeria still operates the old model of inspection practices that were inherited from the colonial government [7]. Evidence today has shown that this old model is ineffective, weak and out dated [5]. In view of the above, the present study is designed to discuss the problems with primary education in the South Western Nigeria, identify causes of decline in 
standard and quality. It is also describe the current efforts at improving the standard and quality in the country. In order to effectively achieve the above objectives, the following research questions are generated.

\section{Research Questions}

After a review of relevant literature on the quality assurance and UBE at the primary school level, this paper will provide empirical answers to the following questions:

- what are the components of Universal Basic Education?

- what is the status of UBE in the two states?

- why the decline in standard and quality of primary school education?

- what are the quality assurance models proposed?

- to what extent are these quality assurance model being implemented or incorporated into UBE?

- What impact does it have on qualities and standard?

\section{Literature Review}

Universal Basic Education is the education provided for children between the ages of three and 14. It is made up of 3 years of Early Childhood Care Development and Education (ECCDE), 3 years of primary and three years of Junior Secondary Education. With specific reference to Nigeria, it covers other special areas like mass literacy, nomadic and migrant children, and the children in the river Rhine areas, almajirias and physically disabled children [5].

On the status of Universal Basic Education, there are still problems and challenges in the provision of facilities, enrolment of pupils and provision of quality teachers. These challenges made the Federal Ministry of Education launch an aggressive National Campaign on "Access" so as to intensify mobilization in support of pupil's enrolment and retention. Not only this, the Ministry of Education also made effort to review and update the Universal Basic Education Act to enforce the provisions that make enrolment and retention of pupils compulsory. According to the UBE Act, the Federal Ministry of Education is to work hand in hand with other organization like National Orientation Agency, National Directorate of Employment and National Poverty Eradication Programme to provide incentives to parents/guardians of school children in areas with low enrolment. It was also planned that by 2011 , provision will be made for 4,000 additional classrooms per annum for pre primary and 22,000additional classrooms per annum for primary education. In addition, 4,407,071 were also planned for Junior Secondary Educational and 3,127, 395 for Early Childhood Care Education. In spite of this development, there still exist some unresolved challenges.

Presently, there is the challenge of professionally qualified teachers. According to Egwu, there are alarming differences between teachers certified qualifications, their actual teaching competence and performance on the job. Statistics revealed that a large number of teachers below National Certificate in Education (NCE) abound in North-East and North-West, (70\%). Based on statistic from Teaches Registration Council of Nigeria, the shot fall in competent, certified and qualified teachers are: 969,078 for Early Child hood Care Development Education: 338,147 for primary education; 581 for JSS, $1,580,000$ for adult literacy and 12,329 nomadic educations.

\subsection{Quality Improvement in Primary Education}

Quality assurance is a mechanism used to evaluate the efficiency and appropriateness of teaching and learning in primary schools so as to ensure the delivery of high quality education. It is also a holistic method of identifying and resolving problem within the educational system in order to ensure continuous quality improvement. It can also be described as means of disseminating information regarding the quality of primary education.

According to Birdsall, Levine and Ibrahim [2], enrolment of children in school, the challenges of access/quality and quality of teaching and facilities must be resolved if schools are to offer quality education. $\{2\}$ According to Bateman, quality assurance includes defined standards of achievement, documented procedures for all identified processes, established ways of responding to issues and clear accountability for outcomes. $\{1\}$ The importance of consistence and continuous quality assurance in primary education are many. Some of these benefits associated with consistent quality assurance and continuous Quality improvement measure in education include:

- the establishment of establish high standards academic excellence which will go long way to enhance the schools reputation and image,

- improved communication across the school system,

- Improvement of outcome so that the policies and procedures are constantly revisited through analysis and the delivery of teaching and learning,

- identification of systems strengths and weaknesses, 
- determination of the program effectiveness and tracking of its integrity and;

- $\quad$ increase in capacity to secure funding and refinement service delivery.

\subsection{Standards and Quality Assurance in Nigeria}

According to the National Minimum Standards on Education and Establishment of Institutions Act 16 of 1985 in conjunction with the 1999 Constitution, the Minister of Education was empowered to maintain standards, and quality [6]. This is done by setting minimum standards, maintaining and constantly improving all schools in the Federation. In order to achieve uniform standards, the Federal Ministry of Education delegated the task to the Federal Inspectorate Service (FIS) Department. One weakness of the Education Minimum Standard Act 16, of 1985 is that the FIS was not legally backed by legislation to cover all schools. In this respect the Act 16 of 1985 was amended to provide adequate legal backing for ensuring quality assurance at basic and post-basic education levels. With this amendment, quality assurance in education in Nigeria shifted from the old system of school inspection to constant and continuous monitoring, evaluation and quality improvement processes that provide new operative mode of evaluation. The new system is designed in such away that the evaluation inputs, processes and output meet the set standards so as to bring about improvement in teaching and learning in the foundational class. In summary, quality assurance connotes the goals to which all primary school pupils, teachers, staff and school leaders must achieve. According to National Educational Quality Assurance Policy, Nigeria is concerned with 8 components of quality standards itemized as:

- learner achievement and standards;

- learners welfare and participation;

- $\quad$ care guidance and support;

- leadership and management;

- $\quad$ school community relationship;

- learning environment;

- teaching and learning;

- $\quad$ curriculum and other activities [6].

\section{Methodology}

The study employed descriptive survey design. The sample was selected from primary schools in Southwestern part of Nigeria, precisely Oyo and Osun States. A sample of 600 primary school teachers was selected from eleven L.G. Areas within the two states. The research instrument used is made up of interview schedule and observational checklist scale. The questionnaire schedule contained 56 items that were divided into four sections. Section 1 concerns the demographical data of the sample; section II, school facilities and quality. Section III different quality control measures put in place while section IV is concerned with challenges, problems and the impact of the quality assurance model.

\section{Results and Findings}

The data collected in respect of the qualifications of the teachers from the eleven local government areas sampled showed that $62.2 \%$ had National Certificate, 4.8\% Associate Diploma in Education and 13.2\% with Degree in Education. Based on the National Policy on Education (NPE), the minimum basic qualification for teaching in the primary schools in Nigeria is NCE. It implied that majority of the teachers in the two states sampled possess the required qualification. It means that they met the required standard set for would be teachers to teach in primary schools in Nigeria (NPE).

On designation, years of experience and number of pupils per class. Seventy-seven point five percent of the sample was classroom teachers. 7.8\% head teachers 5.7\% Assistant head teachers and $0.5 \%$ local inspectors of education. With respect to teacher's years of experience, the result showed that $10.3 \%$ of the teachers had been in the service between 1 to 2 years, $27.5 \%$ for $3-5$ years. $11.9 \%$ between 6 -8years. $20 \%$ of the teachers spent between 9- 11 years and $27.7 \%$ between 12 years and above. The implication of this to the study is that, majority of the teachers are experienced while only $0.7 \%$ are new entrants.

On the extent of the implementation of the quality model in terms of teacher - pupil's ratio as stipulated in the National Policy on Education, the result of the data collected revealed that most classrooms are overcrowded. Only $4 \%$ of the teachers have 20 students in their classrooms, thirty percent has between 21 and 30 pupils, 51.4\% between 31 and 40 pupils while 3.7\% has 41 and above. The result obtained showed that the schools are yet to adhere strictly to the small class enrolment as stipulated in the UBE and NPE.

In order to ascertain the standard and quality of the schools facilities provided, a one-way analysis of variance was conducted on the following variables (i) adequate classroom facilities (ii) furniture (iii) Elementary Science Laboratories (iv) Library. It is the consensus opinion of educators that for effective learning to occur, the learning environment must be conducive. Not only this, quality facilities such as teaching/learning materials must also be readily available. When the responses of the teachers on schools facilities were compared across the eleven local government areas, the 
analysis of variance for adequate classrooms showed $(\mathrm{F}=7.049$, $\mathrm{df}=1,159 \mathrm{p}<0.05)$ which was significant. For furniture, $(\mathrm{F}=5.546$, df $=(1,516) \mathrm{p}$ $<0.018$ ) condition of furniture whether conducive for learning $(\mathrm{F}=6.160, \mathrm{df}=(1,516) \mathrm{p}<0.013)$. The teacher's response on the condition of the classrooms for teaching and learning revealed that there was a unanimous agreement that the classrooms were $\mathrm{n}$ good condition for teaching and learning $(\mathrm{F}=10.953$, $\mathrm{df}=(1,520) \mathrm{P}<0.01)$. On the availability of Elementary Science Laboratory, functional computers and library in primary schools the results also showed that most schools do not have elementary science laboratory ( $\mathrm{F}$ $=0.460$, df $=(1,519) \mathrm{P}>0.498)$ and few schools have computer room $(\mathrm{F}=0.159$, $\mathrm{df}=(1.520) \mathrm{P}>$ 0.979). The result however showed that there are well equipped library $(\mathrm{F}=8.159$, $\mathrm{df}=(1,508)$ $\mathrm{P}<0.04)$. With regards to space, the result obtained revealed that the teachers were of the opinion that it is spacious and conducive for both students and teacher's use $(\mathrm{F}=4.751$, df $=(1,519) \quad \mathrm{P}<0.03)$. Finally on availability of sports facilities in the selected schools, the result showed that the selected schools have sporting facilities $(\mathrm{F}=6.39$, $\mathrm{df}=$ $(1,153) \mathrm{P}<0.012)$. To determine the quality of the instruction given to the pupils, an assessment of the lesson given was carried out. The area assessed are: teacher's lesson notes, the stated objectives, the tests given, assignments, availability of test blue prints and tables of specification. The results revealed that teaching was of good quality. Also the teachers stated instructional objectives are well stated $(\mathrm{F}=3.453$, df $=1,531 \mathrm{p}<0.064)$. The stated objectives are also relevant $(\mathrm{F}=5.271$, $\mathrm{df}=(1,525)$ $\mathrm{p}<0.022$ ). However on the quality of the type of classroom tests administered, the results revealed that they were of poor quality. Results also showed that the tests given to the pupils were relevant $(\mathrm{F}=$ 1.76) $\mathrm{df}=(1,526) \mathrm{p}<0.0185)$ but inappropriate $(\mathrm{F}=0.439, \mathrm{df}=(1,524) \mathrm{P}>0.508)$. It also showed that the coverage and contents were inadequate $(\mathrm{F}=0.292$, df $=(1,525), \quad \mathrm{P}>0.589)$. One can conveniently say the tests administered were inappropriate and inadequate. The reasons are not far fetched; this is because there are no test blue prints and table of specification $(\mathrm{F}=0.22$, $\mathrm{df}=$ (1,513), $\mathrm{P}>0.883)$. With respect to the quality of school inspection, the areas assessed are: frequency of inspection, student's attendance register and teacher's Record of work, Schools Diary and Mark sheets. An assessment was carried out on them, to determine whether they are well kept and whether the pupil's scores are credible. The results obtained revealed that schools supervision, monitoring and inspection are frequency $(\mathrm{F}=3.461$, $\mathrm{df}=(1,505)$ $\mathrm{P}<0.063)$. However Schools Diaries are not kept up to date $(\mathrm{F}=0.812 \mathrm{df}=(1,523) \mathrm{P}>0.368)$. Attendance Registers are also not signed and kept up to date $(\mathrm{F}=0.059$, $\mathrm{df}=(1.526) \mathrm{P}>0.809)$. This has serious implication for schools and this trend must be corrected.

With respect to the adequacy of the teachers mark sheets, the result of the data collected showed that the pupils scores that the teachers entered into them were credible $(\mathrm{F}=2.15$, df $-(1,522)$, $\mathrm{P}<0.143)$. It also revealed that the dates the scores entered were indicated and signed $(\mathrm{F}=5.147$, $\mathrm{df}=$ (1.522) $\mathrm{P}<0.024)$. It therefore means that the pupil's scores as entered by the teachers are credible and reliable.

\section{Conclusion}

The following summary is made based on the results of the analyzed. The teachers in the selected schools are qualified and well experienced. There are more female teachers (66\%) than the male teachers (34\%). Most classrooms are overcrowded. This implied that schools are yet to adhere to the teacher-pupils ratio of 30 pupils in a class. Schools facilities, classroom items and furniture are adequate. Library facilities were provided and adequate. Schools do not have science laboratories. Attendance register and record of works were poorly kept in schools. There is constant monitoring, supervision and inspection of schools. The class tests and examination questions were of poor standard. This is due to lack of table of specifications. In addition the language of construction is in adequate and inappropriate.

\section{Recommendations}

The present study has revealed that the current effort of the federal and state government at revamping primary education has objectively yielded good fruits. However much needs to be done in the area of: provision of modern Elementary Science laboratories and ICT facilities in the primary schools across the country. Workshops and training should be provided to equip the teachers on how to develop reliable and quality test items for teachers. Proper keeping of school Attendance Registers, Schools Diary and other records are of paramount importance. Also schools inspection should be more thorough. Decongest the over crowded classrooms to a smaller class size. Construct modern classrooms equipped with basic amenities so that there will be facilities for the new nine years in the primary schools (9-3-5 system of education). There is also the need for the recruitment of more qualified teachers.

\section{References}

[1] Bateman, P., (2006), Quality Assurance mechanisms open, distance e-learning (O-Del). A lead paper 
presented at a workshop organized by African Virtual University, Kenya in collaboration with Carnegie Corporation and Information Technology and Communication Unit Obafemi Awolowo University, IleIfe.

[2] Birdsall, N., Levince, R., Ibrahim A., (2006) Building gender equality in urban life. Global Urban Research Development Magazine.Vol.2 Issue 1, pp. 9-14.

[3] Chua, A., and Wing, I., (2007) Quality assurance in an online education. The Universities 21 global appraisal British Journal of Educational Technology Vol. 38, No. 1 pp 133-152.

[4] Daily News, (2010), Expansion of Primary Education in Nigeria. Today News, Thursday, December 30, 2010. Retrieved from www.onlinenigeria. com.

[5] Egwu, S. O., (2009), Roadmap for Nigerian educational sector Abuja Federal Ministry of Education, Federal Ministry of Education Abuja.

[6] National Policy on Education, (2004), Lagos NERDC.

[7] Omotayo, D., Ihebereme, M. and Maduewesi, B. U., (2008) Management of Universal Basic Education (UBE) Scheme for Qualitative Education in Nigeria. High Beam Research.

[8] Organization for Economic Cooperation and Development, (OECD 2005). Teachers matter. Attracting and retaining effective teachers proceeding of OECD.

[9] Soudien, C., (2007), Making our own modernity: Standards, values and bench mark in the schools in the age of globalization. In South African Review of Education vol. 13. No. 1 pp. 7-17.

[10] Teachers' Registration Council of Nigeria, (TRCN 2007) Statistical digest on teachers in Nigeria for quality in education TRCN Vol. 1, No. 33 pp. 10-15.

[11] UNESCO, (1990), World declaration on 'educational needs and frame work for action to meet the basic learning needs. Adopted by the World Conference on Education Forum. Dakar, Senegal.

[12] UNESCO, (2001), General Assembly Resolution and Road map Towards the Implementation of the Millennium Development Declaration. $56^{\text {th }}$ Sessions item 40 of the Provision of the Agenda and Follow-up and the outcome of the Millennium Development Summit. New York.

[13] Weiss, M. A., (2006), Towards Universal Primary Education: United Nations Millennium Project Report on Education and Gender quality. Vol. 2, No. 1 Published by Global Urban Development. 